\title{
Economic values of growth and feed efficiency for fish farming in recirculating aquaculture system with density and nitrogen output limitations: a case study with African catfish (Clarias gariepinus) ${ }^{1}$
}

\author{
M. Besson, ${ }^{+}+\dagger^{2}$ H. Komen, * J. Aubin, $§$ I. J. M. de Boer,\# \\ M. Poelman, || E. Quillet, $\$$ C. Vancoillie, $₫$ M. Vandeputte, $\$$ and J. A. M. van Arendonk* \\ *Animal Breeding and Genomics Centre, Wageningen University, P.O. Box 338, NL-6700 AH Wageningen, the Netherlands; \\ $\uparrow$ AgroParisTech, UMR1313 Génétique animale et biologie intégrative, 16 rue Claude Bernard, F-75231 Paris 05, France; \\ \$INRA, UMR1313 Génétique animale et biologie intégrative, Allée de Vilvert, F-78350 Jouy-en-Josas, France; §INRA, \\ Agrocampus Ouest Rennes, UMR1069 Sol Agronomie Spatialisation, 65 rue de Saint Brieuc, F-35042 Rennes, France; \\ \#Animal Production Systems group, Wageningen University, P.O. Box 338, NL-6700 AH Wageningen, the Netherlands; \\ || IMARES, Wageningen UR, Korringaweg 5, NL-4401 NT Yerseke, the Netherlands; ๆFishion Breeding, Breedijk 13, \\ NL-5705 CJ Helmond, the Netherlands; and 'IFREMER, Chemin de Maguelone, F-34250 Palavas-les-Flots, France
}

ABSTRACT: In fish farming, economic values (EV) of breeding goal traits are lacking, even though they are key parameters when defining selection objectives. The aim of this study was to develop a bioeconomic model to estimate EV of 2 traits representing production performances in fish farming: the thermal growth coefficient (TGC) and the feed conversion ratio (FCR). This approach was applied to a farm producing African catfish (Clarias gariepinus) in a recirculating aquaculture system (RAS). In the RAS, 2 factors could limit production level: the nitrogen treatment capacity of the biofilter or the fish density in rearing tanks at harvest. Profit calculation includes revenue from fish sales, cost of juveniles, cost of feed, cost of waste water treatment, and fixed costs. In the reference scenario, profit was modeled to zero. EV were calculated as the difference in profit per kilogram of fish between the current population mean for both traits $\left(\mu_{t}\right)$ and the next generation of selective breeding $\left(\mu_{t}+\Delta_{t}\right)$ for either TGC or FCR. EV of TGC and FCR were calculated for three generations of hypothetical selection on either TGC or FCR (respectively $6.8 \%$ and $7.6 \%$ improvement per generation). The results show that changes in TGC and FCR can affect both the number of fish that can be stocked (number of batches per year and number of fish per batch) and the factor limiting production. The EV of TGC and FCR vary and depend on the limiting factors. When dissolved $\mathrm{NH}_{3}-\mathrm{N}$ is the limiting factor for both $\mu_{\mathrm{t}}$ and $\mu_{\mathrm{t}}+\Delta_{\mathrm{t}}$, increasing TGC decreases the number of fish that can be stocked but increases the number of batches that can be grown. As a result, profit remains constant and $\mathrm{EV}_{\mathrm{TGC}}$ is zero. Increasing FCR, however, increases the number of fish stocked and the ratio of fish produced per kilogram of feed consumed ("economic efficiency"). The $\mathrm{EV}_{\mathrm{FCR}}$ is $0.14 € / \mathrm{kg}$ of fish, and profit per kilogram of fish increases by about $10 \%$. When density is the limiting factor for both $\mu_{\mathrm{t}}$ and $\mu_{t}+\Delta_{t}$, the number of fish stocked per batch is fixed; therefore, extra profit is obtained by increasing either TGC, which increases the annual number of batches, or by decreasing FCR, which decreases annual feed consumption. $\mathrm{EV}_{\mathrm{TGC}}$ is $0.03 € / \mathrm{kg}$ of fish and $\mathrm{EV}_{\mathrm{FCR}}$ is $0.05-0.06 € / \mathrm{kg}$ of fish. These results emphasize the importance of calculating economic values in the right context to develop efficient future breeding programs in aquaculture.

Key words: economic values, feed conversion ratio,

fish farming, recirculating aquaculture system, selective breeding, thermal growth coefficient.

(C) 2014 American Society of Animal Science. All rights reserved.

J. Anim. Sci. 2014.92:5394-5405 doi:10.2527/jas2014-8266

\footnotetext{
${ }^{1} \mathrm{M}$. Besson benefited from a joint grant from the European Commission and IMARES, within the framework of the ErasmusMundus joint doctorate "EGS-ABG." Mathieu Besson is grateful to Gus Rose for his advice on programming in $\mathrm{R}$.
}

${ }^{2}$ Corresponding author: mathieu.besson@wur.nl Received July 10, 2014. Accepted October 8, 2014. 


\section{INTRODUCTION}

On a global scale, fish-farming production doubled over the last 10 years (FAO, 2012), and breeding programs are considered a key step in the development of fish farming (Gjedrem et al., 2012). In most terrestrial livestock breeding programs, genetic improvement is realized through selection on a breeding objective, defined as a linear function of traits to be improved, each trait weighted by its economic value (EV; Hazel, 1943). EV expresses the economic benefit/loss obtained from genetic improvement of a trait in a production system (Groen, 1988). In Nile tilapia (Oreochromis niloticus), Ponzoni et al. (2007) estimated that breeding for harvest weight, feed intake, and survival over 10 years can have positive economic returns of $\$ 32$ million at the national level. In most farmed fish species, however, EV of breeding goal traits are lacking, and genetic improvements are mostly realized using breeding objectives that describe the desired rate and direction of genetic change for a set of traits in a breeding goal (e.g., Sae-Lim et al., 2012). Groen (1988) suggested modeling production at the farm level to determine EV of each trait while considering limitations constraining production. When limitations are applied, EV of traits may change and breeding goals have to be adapted for such limitations (Gibson, 1989; Groen, 1989).

This study aimed, therefore, to develop a bioeconomic model to calculate EV for 2 key traits in fish farming: the thermal growth coefficient (TGC) and the feed conversion ratio (FCR). We investigated African catfish (Clarias gariepinus) reared in a recirculating aquaculture system (RAS) as a case study for 2 reasons. (1) A RAS is an interesting development model for fish farming, which includes treatment loops for a better water and waste management (Martins et al., 2010; van Rijn, 2013). (2) In RAS, 2 factors could limit production, the nitrogen treatment capacity of the biofilter or the fish density in tanks, which suggest changes in EV of TGC and FCR.

\section{MATERIAL AND METHODS}

\section{Farm Design}

A typical commercial Dutch RAS farm producing about $500 \mathrm{t}$ of African catfish indoor per year was modeled using R software (R Development Core Team, 2008). The RAS parameters were based on information from Fishion Breeding, Viqon Water Solutions, and Skretting. In this indoor system, water was thermoregulated at $27^{\circ} \mathrm{C}$ through regulating the ambient air temperature. The RAS was composed of 4 main compartments: a series of 20 rearing tanks ( 6 tanks of $6 \mathrm{~m}^{3}$ for fish from 13 to $80 \mathrm{~g}$ and 14 tanks of $50 \mathrm{~m}^{3}$ for fish from 80 to $1,300 \mathrm{~g}$ ); a mechani- cal filter, which removed solid waste; a biofilter where nitrifying bacteria broke down ammonia into nitrites and nitrates; and a denitrification reactor where denitrifying bacteria processed nitrates into nitrogen. Clean-up water was reused in rearing tanks, and only $30 \mathrm{~m}^{3} /$ day of effluent water was directed to a waste water treatment plant, which corresponds to $96 \%$ of recirculation. The time needed for a fish to grow from 80 to $1,300 \mathrm{~g}$ represented one production cycle. During one cycle, 14 batches of fish were stocked successively in the 14 tanks. A batch of fish was defined as a group a fish of the same age stocked in the same tank. Consequently, fish biomass reached a peak just before the oldest batch was harvested and the maximum standing stock (MSS) was reached (Fig. 1).

\section{Individual Growth Model}

Fish growth was modeled based on the TGC from Dumas et al. (2007). The 2 main model assumptions are that growth rate is allometrically related to body weight ( $\mathbf{W}$ in $\mathrm{g}$ ) and that growth rate is an allometric constant related to mean daily water temperature averaged over the rearing period (Dumas et al., 2007)

$$
\mathrm{TGC}=\frac{\mathrm{W}_{\mathrm{H}}^{1-\mathrm{b}}-\mathrm{W}_{\mathrm{I}}^{1-\mathrm{b}}}{\sum_{\mathrm{i}=1}^{\mathrm{n}} \mathrm{T}_{\mathrm{i}}},
$$

where $\mathrm{n}$ is the number of days between initial $\left(\mathbf{W}_{\mathbf{I}}\right)$ and harvest $\left(\mathbf{W}_{\mathbf{H}}\right)$ weight and $\mathrm{T}$ is the mean daily temperature at day $\mathrm{n}$ (constant to $27^{\circ} \mathrm{C}$ ). 1-b is a weight exponent specific to a species (Dumas et al., 2007). This weight exponent was set at 0.475 in order to fit the growth curve obtained by the TGC equation to the growth curve of African catfish commonly observed in farms $(13 \mathrm{~g}$ to $1,300 \mathrm{~g}$ in 119 days at $\left.27^{\circ} \mathrm{C}\right)$. Fish weight at day $\mathrm{n}\left(\mathbf{W}_{\mathbf{n}}\right)$ and daily weight gain at day $n\left(\mathbf{D W G}_{\mathbf{n}}\right)$ were calculated as

$$
\begin{aligned}
& \mathrm{W}_{\mathrm{n}}=\left[\mathrm{W}_{\mathrm{I}}^{0.475}+\left(\mathrm{TGC} \times \sum_{\mathrm{i}=1}^{\mathrm{n}} \mathrm{T}_{\mathrm{i}}\right)\right]^{1 / 0.475}, \\
& \mathrm{DWG}_{\mathrm{n}}=\mathrm{W}_{\mathrm{n}}-\mathrm{W}_{\mathrm{n}-1} .
\end{aligned}
$$

Feed utilization efficiency was expressed as FCR, defined as a unit of feed consumed divided by a unit of body mass gain. FCR is a parameter depending on the life stage of fish that increases as fish size/age increases (Robinson and Li, 2010). FCR was, therefore, modeled as a power function of $\mathrm{W}_{\mathbf{n}}\left(\mathbf{F} \mathbf{C} \mathbf{R}_{\mathbf{W n}}\right)$, using data from commercial feed trials, in order to keep the same FCR among different growth rate scenarios:

$$
\mathrm{FCR}_{\mathrm{Wn}}=0.37 \times \mathrm{W}_{\mathrm{n}}^{0.112}
$$




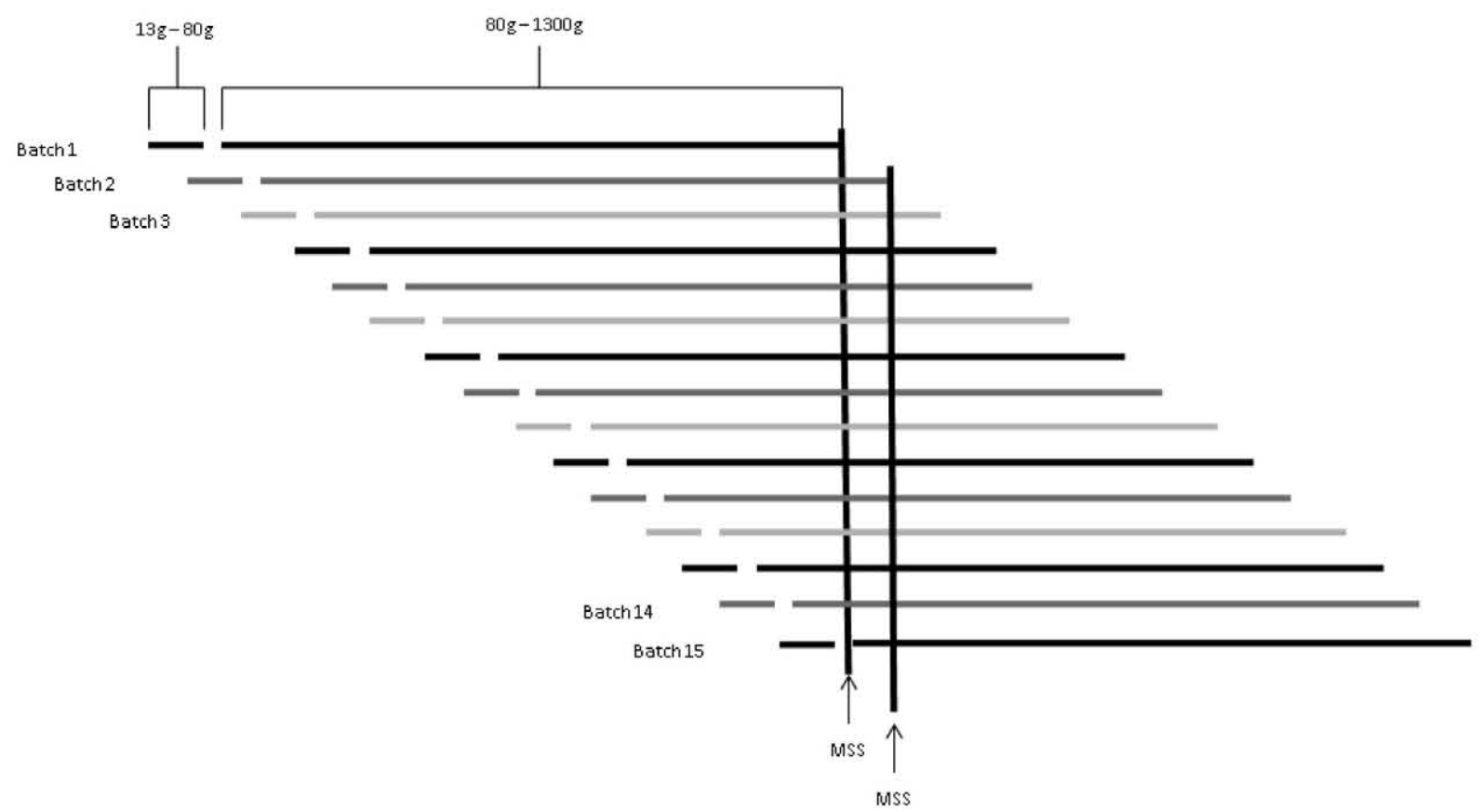

Figure 1. Production scheme of a typical African catfish RAS in the Netherlands.

In the present model, we assumed that TGC and FCR were not related and that a change in one of these parameters did not modify the other. Using $\mathrm{DWG}_{\mathrm{n}}$ and $\mathrm{FCR}_{\mathrm{Wn}}$, individual daily feed intake at day $\mathrm{n}\left(\mathbf{D F I}_{\mathbf{n}}\right)$ was calculated as well as individual daily feed distributed $\left(\mathbf{D F D}_{\mathbf{n}}\right)$ assuming $1 \%$ of feed wastage (not consumed by the fish):

$$
\begin{aligned}
& \mathrm{DFI}_{\mathrm{n}}=\mathrm{DWG}_{\mathrm{n}} \times \mathrm{FCR}_{\mathrm{Wn}}, \\
& \mathrm{DFD}_{\mathrm{n}}=\mathrm{DFI}_{\mathrm{n}} \times 1.01 .
\end{aligned}
$$

\section{Individual Waste Excretion Model}

The concentration of nitrogen, expressed as ammoniacal nitrogen $\left(\mathbf{N H}_{\mathbf{3}}-\mathbf{N}\right)$ and the chemical oxygen demand (COD) in effluent water was calculated using a mass-balance approach (Cho and Kaushik, 1990; Cowey and Cho, 1991). Details of the calculations for $\mathrm{NH}_{3}-\mathrm{N}$ emission and COD are shown in appendix 2 and 3, respectively. The first step to model $\mathrm{NH}_{3}-\mathrm{N}$ excretion was to calculate the amount of nitrogen $(\mathbf{N})$ provided by the feed eaten and wasted at day $\mathbf{n}$ ( $\mathbf{N}$ feed_intake $\mathbf{n}_{\mathbf{n}}$ and $\mathbf{N}$ _feed_waste $\mathbf{n}_{\mathbf{n}}$ ) and the amount of $\overline{\mathrm{N}}$ fixed by the fish at day n ( $\left.\mathbf{N}_{-} \mathbf{f i s h} \mathbf{n}_{\mathbf{n}}\right)$ (the composition of the feed is given in Appendix 1 ):

$$
\text { N_feed_intake }=72 \times \mathrm{DWG}_{\mathrm{n}} \times \mathrm{FCRW}_{\mathrm{n}} \text {, }
$$

$$
\mathrm{N} \_ \text {feed_waste }{ }_{\mathrm{n}}=\mathrm{N} \_ \text {feed_intake } \mathrm{n} \times 0.01,
$$

$$
\mathrm{N}_{-} \text {fish }_{\mathrm{n}}=24.5 \times \mathrm{DWG}_{\mathrm{n}}
$$

where 72 is the $\mathrm{N}$ content of feed (in $\mathrm{g} / \mathrm{kg}$ of feed) calculated as the protein content of the feed (45\%) divided by 6.25 and 24.5 is the $\mathrm{N}$ content of fish (in $\mathrm{g} / \mathrm{kg}$ of fish) calculated via the $\mathrm{N}$ content of the feed multiplied by the $\mathrm{N}$ retention capacity of African catfish, 34\% (Salhi et al., 2004; van Weerd et al., 1999). The total individual $\mathrm{NH}_{3}-\mathrm{N}$

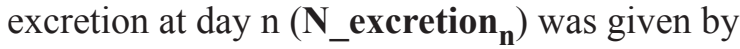

$$
\text { N_excretion } n=\text { N_feed_intake }{ }_{n}-N_{-} \text {fish }{ }_{n} \text {. }
$$

Calculation of the suspended (N_suspended $\mathbf{n}_{\mathbf{n}}$ ) and dissolved (N_dissolved $\mathbf{n}$ ) was given by

$$
\text { N_suspended }{ }_{\mathrm{n}}=6.732 \times \mathrm{FCR}_{\mathrm{Wn}} \times \mathrm{DWG}_{\mathrm{n}} \text {. }
$$

N_dissolved ${ }_{\mathrm{n}}$ was needed to calculate the MSS and was calculated from Eq. [8], [10], and [11] as follows:

$$
\begin{aligned}
& \text { N_dissolved }{ }_{\mathrm{n}}=\text { N_excretion }{ }_{\mathrm{n}}+ \\
& \text { N_feed_waste }{ }_{n}-\bar{N} \text { suspended }_{n} \text {, } \\
& \text { N_dissolved }{ }_{n}=\operatorname{DWG}_{\mathrm{n}}\left(\left(65.988 \times \mathrm{FCR}_{\mathrm{Wn}}\right)-25\right) \text {. }
\end{aligned}
$$

The amount of $\mathrm{NH}_{3}-\mathrm{N}$ in effluent water (N_eff $)$ was calculated as

$$
\text { N_eff }{ }_{\mathrm{n}}=0.1 \times \mathrm{N}_{-} \text {suspended }_{\mathrm{n}} \text {. }
$$


To calculate COD in effluent water, we first need to calculate the COD of feed wasted at day n (COD_waste $)$ and the COD of organic excretions of the fish (COD_excretion $_{\mathbf{n}}$ ). COD_waste ${ }_{\mathrm{n}}$ was calculated according to protein, crude fat, and carbohydrate concentration in the feed wasted at day $\mathrm{n}$ (in $\mathrm{kg} / \mathrm{kg}$ of feed) multiplied by the stoichiometric oxygen demand (in $\mathrm{kg}$ of $\mathrm{O}_{2}$ per $\mathrm{kg}$ of feed) of these elements $\left(\mathbf{C O D} \mathbf{p}_{\mathbf{p}}=1.66, \mathbf{C O D}_{\mathbf{C F}}=2.78\right.$ and $\left.\mathbf{C O D}_{\mathbf{C}}=1.19\right)$ :

$$
\begin{aligned}
& \text { COD_waste }_{\mathrm{n}}=\left(\mathrm{COD}_{\mathrm{P}} \times 0.013+\mathrm{COD}_{\mathrm{CF}} \times\right. \\
& \left.0.029+\mathrm{COD}_{\mathrm{C}} \times 0.0107\right) \times \mathrm{DFI}_{\mathrm{n}} .
\end{aligned}
$$

COD_excretion $n$ was calculated using feed eaten at day $\mathrm{n}$ and the digestibility of proteins, crude fat, and carbohydrates:

COD_excretion ${ }_{\mathrm{n}}=($ protein $\times 0.13+$ crude_fat $\times$

$0.29+$ carbohydrates $\times 0.428) \times \mathrm{DFI}_{n}$.

With COD_waste $\mathrm{n}_{\mathrm{n}}$ and COD_excretion $\mathrm{n}$, we can calculate COD required to oxidize the organic matter remaining in effluent water (COD_eff

$$
\begin{aligned}
& \text { COD_eff } \\
& 0.24+\text { carbohydrates } \times 0.33) \times \text { DFI }_{n} .
\end{aligned}
$$

\section{Batch Model}

The amount of dissolved $\mathrm{NH}_{3}-\mathrm{N}$ excreted per day per fish was used at batch level to calculate the maximum number of fish that could be stocked per batch $\left(\mathbf{N b} \mathbf{f i s h}_{\mathbf{0}}\right)$.

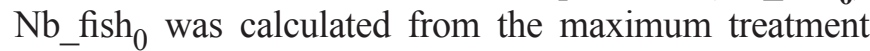
capacity of the biofilter (maximum $\mathrm{NH}_{3}-\mathrm{N}$ load in $\mathrm{kg}$ of $\mathrm{NH}_{3}-\mathrm{N}$ per day), which was fixed and dependent on the

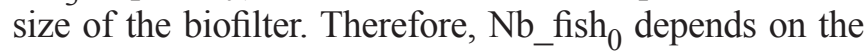
cumulative individual excretion of $\mathrm{NH}_{3}-\mathrm{N}$ of all fish in all 14 batches ( $\mathrm{j}=1$ to 14$)$ at MSS (N_dissolved $\mathbf{M S S}_{\text {). }}$.

$$
\mathrm{Nb}_{-} \text {fish }_{0}=\frac{\text { maximum } \mathrm{NH}_{3}-\mathrm{N} \text { load }}{\sum_{\mathrm{i}=1}^{\mathrm{j}}\left(\mathrm{N}_{-} \operatorname{dissolved}_{\mathrm{MSS}(\mathrm{j})}\right) \times\left(1-\mathrm{M}_{\mathrm{Wn}(\mathrm{j})}\right)}
$$

N_dissolved ${ }_{M S S(j)}$ was calculated from Eq. [13] for each batch $\mathrm{j} . \mathrm{M}_{\mathrm{Wn}(\mathrm{j})}$ was the cumulative mortality at fish weight $\mathrm{W}_{\mathrm{n}}$ in batch $\mathrm{j}$. Cumulative mortality was modeled as a linear function of fish weight:

$$
\mathrm{M}_{\mathrm{Wn}}=0.0001 \times \mathrm{W}_{\mathrm{n}}+0.0113,
$$

where $1-\mathrm{M}_{1300}$ corresponds to a total survival of about $85 \%$ from stocking to harvest size. With $\mathrm{Nb}_{-}$fish $_{0}$ and $\mathrm{M}_{\mathrm{Wn}}$, daily number of fish, daily feed consumption, daily waste excretions, and finally, production of fish at batch level were calculated.

\section{Farm Model}

The number of $50 \mathrm{~m}^{3}$ tanks available was used to calculate the number of batches stocked per year. The number of batches, therefore, depended on the time interval between batches defined by the time needed for a batch to grow from $80 \mathrm{~g}$ to $1,300 \mathrm{~g}$ at $27^{\circ} \mathrm{C}$ (Nb_days) and by the number of tanks available $(\mathbf{N b}$ tanks $=14)$ :

$$
\begin{aligned}
& \mathrm{Nb}_{-} \text {days }=\frac{\left(\mathrm{W}_{\mathrm{H}}^{0.475}-\mathrm{W}_{\mathrm{I}}^{0.475}\right) \times 27}{\mathrm{TGC}}=\frac{597.30}{\mathrm{TGC}}, \\
& \mathrm{Nb} \_ \text {batch }{ }_{\text {year }}=\frac{365 \times 14}{\mathrm{Nb} \_ \text {days }}= \\
& \frac{5510}{\mathrm{Nb} \_ \text {days }}=9.22 \times \mathrm{TGC} \text {. }
\end{aligned}
$$

Annual fish production, feed consumption, and waste excretions at the farm level were calculated from the number of batches per year and total kilograms of fish produced per batch, total feed consumption per batch of fish, and waste excretions per batch. The average realized FCR over the year was calculated as

$$
\mathrm{FCR}=\frac{\text { feed distributed per year }}{\text { fish production per year }} .
$$

\section{Limiting Factors}

In our production system of catfish in RAS, 2 factors could limit fish production at the farm level. The first one is the rearing density of fish, which was set at $230 \mathrm{~kg} / \mathrm{m}^{3}$, according to best practice recommendations. This maximum density value is chosen such that oxygen concentrations will stay well above $4 \mathrm{ppm}$, resulting in optimized fish growth and fish welfare. The volume of a production tank was $50 \mathrm{~m}^{3}$; therefore, the maximum amount of fish harvested per batch was limited to $11,500 \mathrm{~kg}$ or 8,846 fish of $1.3 \mathrm{~kg}$. The second limiting factor depended on the maximum dissolved $\mathrm{NH}_{3}-\mathrm{N}$ treatment capacity of the biofilter, or maximum $\mathrm{NH}_{3}-\mathrm{N}$ load, reached at MSS. In our situation, the volume available for bacteria biomass (biomedia) was $150 \mathrm{~m}^{3}$ and the maximum $\mathrm{NH}_{3}-\mathrm{N}$ load was equal to $39 \mathrm{~kg}$ of dissolved $\mathrm{NH}_{3}-\mathrm{N}$ at MSS. There were, therefore, 2 different and distinct ways to calculate $\mathrm{Nb}_{-}$fish ${ }_{0}$ according to the limiting factor. When density was the limiting factor, the number of fish harvested was fixed to 8,846 fish per batch. When dissolved $\mathrm{NH}_{3}-\mathrm{N}$ was the limiting factor, however, $\mathrm{Nb}$ fish $_{0}$ varied depending on N_dissolved ${ }_{\text {MSS }}$ per batch (Eq. [18]).

\section{Economic Parameters and Economic Profit}

A summary of fixed and variable costs is given in Table 1. Fixed costs represented, in total, 164,204 € per year for a farm producing $500 \mathrm{t}$ of fish per year. The calculation of 
Table 1. Revenue and costs (variable and fixed) of an African catfish RAS in the Netherlands

\begin{tabular}{|c|c|c|}
\hline Item & Abbreviation & Value \\
\hline \multicolumn{3}{|l|}{ Variable revenue } \\
\hline fish & Rfish & $1.35 € / \mathrm{kg}$ of fish \\
\hline \multicolumn{3}{|l|}{ Variable Costs } \\
\hline feed & Cfeed & $1.10 € / \mathrm{kg}$ of feed \\
\hline juveniles & Cjuveniles & $0.14 € /$ unit \\
\hline discharged water & Cp.u. & $43.2 € /$ p.u. \\
\hline \multicolumn{3}{|l|}{ Fixed costs } \\
\hline insurance & Cins & $5,000 €$.farm ${ }^{-1}$.year-1 \\
\hline administration & Cadm & $5,000 €$. farm $^{-1} \cdot$ year $^{-1}$ \\
\hline work & Cwork & $30,000 €$. farm $^{-1}$. year $^{-1}$ \\
\hline rent & Crent & $70,000 €$. farm $^{-1}$. year $^{-1}$ \\
\hline maintenance & Cmaint & $10,000 €$. farm $^{-1}$.year ${ }^{-1}$ \\
\hline energy & Cenrg & $30,000 €$ farm $^{-1}$.year ${ }^{-1}$ \\
\hline sewer & Csewer & $4,204 €$. farm $^{-1}$.year ${ }^{-1}$ \\
\hline unpredictable & Cunp & $10,000 €$. farm $^{-1}$. year $^{-1}$ \\
\hline
\end{tabular}

the Dutch nitrogen taxes was used to calculate the cost of discharged water. This tax was calculated in pollution units (p.u.), which was expressed in quantity of oxygen needed to break down organic pollution produced per person and per year $(1$ p.u. $=49.6 \mathrm{~kg}$ of oxygen $)$ :

$$
\text { p.u. }=(4.57 \times \text { N_eff }+ \text { COD_eff }) / 49.6 \text {. }
$$

Annual profit per farm (annual_profit) and profit per kilogram of fish produced (profit_fish) were given by (see Table 1 for abbreviations)

annual $\_$profit $=($Number of fish harvested per year $\times$ harvest weight $\times$ Rfish) $(\mathrm{kg}$ feed distributed per year $\times$ Cfeed) - (Number of juveniles stocked per year $\times$ Cjuveniles $)$ - (Nb_p.u. $\times$ Cp.u. $)-$ fixed costs

$$
\text { and profit_fish }=\frac{\text { annual_profit }}{\text { fish production per year }} \text {. }
$$

\section{Economic Values (EV)}

In selection-index theory, the aggregate genotype or breeding goal is usually defined as a linear function of traits to be improved; each trait multiplied by its EV. The EV expresses the value of a unit change in a trait while keeping the other traits in the aggregate genotype constant (Groen, 1988). In our study, the EV of FCR is positive because it represents a predicted change in profit for a specific level of genetic improvement. However, in an aggregate genotype equation, the sign of the EV indicates the direction of desired change. Consequently, in an aggregate genotype equation, the economic value of FCR would be negative because selection is for lower FCR values. The bioeconomic model was used to calculate the economic value (in $€ / \mathrm{kg}$ of fish) of FCR and TGC in three steps.

1) The model was run for the current population mean for trait $t\left(\mu_{t}\right)$ to obtain the initial annual profit per farm, which was divided by annual fish production to obtain profit per $\mathrm{kg}$ of fish (profit_fish ${ }_{\mu \mathrm{t}}$ ).

2) For each trait, the mean was increased after one generation of selection by $\Delta_{\mathrm{t}}$ to $\mu_{\mathrm{t}}+\Delta_{\mathrm{t}}$ while keeping the mean of the other trait at its current value. Percentage of improvement per generation of trait mean obtained after one generation of phenotypic selection on one trait only can be calculated as $i \times h^{2} \times C V$, where $i$ is the intensity of selection, $\mathrm{h}^{2}$ is the heritability, and CV is the coefficient of phenotypic variation. If selection intensity is fixed to 1 (38\% of selected animals), percentage of improvement per generation in TGC and FCR is equal to $\mathrm{h}^{2} \times \mathrm{CV}$. As there are not yet genetic parameters for African catfish, we used genetic parameters of rainbow trout (Oncorhynchus mykiss) as a proxy. In rainbow trout, the $\mathrm{h}^{2}$ and the CV of TGC was found to be 0.32 and 21.23 , respectively (Silverstein et al., 2009), while the $\mathrm{h}^{2}$ and the CV of FCR was found to be 0.17 and 45.69, respectively (Kause et al., 2006). The percentage of improvement per generation (with $\mathrm{i}=1$ ) was, therefore, $6.8 \%$ for TGC and $7.6 \%$ for FCR (Sae-Lim et al., 2012). We used these percentages of improvement per generation to define $\Delta_{\mathrm{TGC}}=\mu_{\mathrm{TGC}} \times(1+0.068)$ and $\Delta_{\mathrm{FCR}}=\mu_{\mathrm{FCR}} \times(1-0.076)$. The model was run a second time when the mean of the trait was increased by $\Delta_{\mathrm{t}}$ to calculate the annual profit per farm after genetic improvement. The annual profit per farm was divided by annual fish production before genetic improvement according to Groen (1989) to obtain profit per kg of fish: $\mu_{t}+\Delta_{t}$.

3) Finally, the economic value per generation was calculated for both traits as

$$
\mathrm{EV}_{t}=\text { profit_fish }{ }_{\mu \mathrm{t}+\Delta \mathrm{t}}-\text { profit_fish }{ }_{\mu \mathrm{t}}
$$

Economic values of TGC and FCR were calculated for 3 generations of selection. Economic values were, therefore, calculated for 16 combinations of TGC and FCR according to 4 TGC values times 4 FCR values. These 4 values of each TGC and FCR were composed of the reference scenario plus 3 generations of selection. In the reference scenario, TGC was 8.33 using Eq. [1] and reference data $\left(119 \mathrm{~d}\right.$ at $27^{\circ} \mathrm{C}$ to reach $1.3 \mathrm{~kg}$ and using $\left.1-\mathrm{b}=0.475\right)$. At the farm level, FCR observed is fluctuating between 0.80 and 0.82. In the reference scenario, therefore, FCR was fixed at 0.81 to balance costs with revenues when TGC 
Table 2. Production parameters for African catfish RAS in the reference scenario, $\mathrm{TGC}=8.33$ and $\mathrm{FCR}=0.81$

\begin{tabular}{lc}
\hline \hline Production Parameter & Value \\
\hline Number of fish harvested per batch & 7,667 \\
Stocking density at harvest & $199 \mathrm{~kg} / \mathrm{m}^{3}$ \\
Number of batches per year & 52 \\
Production of fish per year & $518 \mathrm{t}$ \\
Feed consumption per year & $420 \mathrm{t}$ \\
$\mathrm{NH}_{3}-\mathrm{N}$ dissolved at MSS & $39 \mathrm{~kg}$ \\
Profit per farm per year & $0 €$ \\
\hline
\end{tabular}

$=8.33$. Hence, the $4 \mathrm{TGC}$ values were $8.33,8.9,9.5$, and 10.15 , and the 4 FCR values were $0.81,0.75,0.69$, and 0.64 . The different FCR values were obtained by varying only the weight exponent of the $\mathrm{FCR}_{\mathrm{wn}}$ formula (Eq. [4]). Varying only the constant of Eq. [4] produces unrealistic values in the lower fish weight range. The practical consequence of varying only the weight exponent of Eq. [4] was that improvement of FCR will mostly be due to better feed conversion in late life.

\section{RESULTS}

\section{Reference Scenario}

Production parameters of the reference scenario show that the 2 limiting factors are well respected. The density at harvest time is under $230 \mathrm{~kg} / \mathrm{m}^{3}$, and the quantity of dissolved $\mathrm{NH}_{3}-\mathrm{N}$ at MSS equals $39 \mathrm{~kg}$ (Table 2). In the reference scenario, dissolved $\mathrm{NH}_{3}-\mathrm{N}$ is, therefore, the limiting factor. Production per year is, moreover, close to what is projected from the design parameters of the farm (500 $\mathrm{t}$ of fish per year). Total annual production cost is about $699,036 €$, of which cost of feed represents $66 \%$ of total costs (variable + fixed) while fixed costs represent $23 \%$. The costs of juveniles and of waste water discharge (p.u.) represent $9.3 \%$ and $1.7 \%$ of the total costs, respectively.

\section{Annual Profit per Farm in Tested Scenarios}

The 2 limitations are acting in the system but only one is relevant at any given time, depending on the level of TGC and FCR. For the sake of clarity, these 2 situations were first analyzed separately: 1) when only dissolved $\mathrm{NH}_{3}-\mathrm{N}$ discharged was the limiting factor and 2) when only fish density at harvest was the limiting factor. Then, the impact of both limitations combined on profit per year per farm was studied.

\section{Limitation on Dissolved $\mathrm{NH}_{3}-\mathrm{N}$ at MSS (Table 3)}

When only dissolved $\mathrm{NH}_{3}-\mathrm{N}$ is the limiting factor, the number of fish stocked and harvested per batch var- ies depending on FCR and TGC values (Table 3 and Eq. [18]). A decrease in FCR (at the same TGC) increases farm profit per year. Lower FCR results in lower total feed distributed per fish (Eq. [5]), and therefore lower dissolved $\mathrm{NH}_{3}-\mathrm{N}$ (Eq. [13]). Hence, the number of fish stocked per batch can be increased in order to reach the limitation on dissolved $\mathrm{NH}_{3}-\mathrm{N}$, which increases the annual production of fish. The amount of feed distributed per year also increases, but less than the annual production of fish. Consequently, the ratio of fish sales over cost of feed increases, resulting in higher profit.

An increase in TGC (at the same FCR) does not change profit in this particular situation. This can be explained by the fact that faster growing fish have higher daily weight gain, which increases dissolved $\mathrm{NH}_{3}-\mathrm{N}$ per fish (Eq. [13]). Fewer fish, therefore, should be stocked to respect the limitations on dissolved $\mathrm{NH}_{3}-\mathrm{N}$, resulting in fewer fish harvested per batch (Eq. [18]). This decreasing number of fish is offset by rearing more batches (Eq. [21]). Therefore, annual fish production as well as feed consumption does not change and profit stays constant over different TGC values. It can be concluded that when dissolved $\mathrm{NH}_{3}-\mathrm{N}$ alone is the limiting factor, extra profit is obtained only by decreasing FCR, which increases productivity and feed consumption.

\section{Limitation on Fish Density at Harvest Time (Table 4)}

When only fish density is the limiting factor, the number of fish harvested per batch is constant and equal to 8,846 fish (Table 4). A decrease in FCR (at the same TGC) does not have an impact on the annual production of fish. The total feed distributed per fish, however, decreases resulting in lower annual feed consumption. Consequently, profit increases with decreasing FCR.

An increase in TGC (at the same FCR) also increases profit. As the number of fish harvested per batch is constant, the number of batches per year increases linearly with TGC (Eq. [21]). Hence, profit increases when TGC increases because the share of fixed costs in total costs decreases. It can be concluded that when density alone is the limiting factor, extra profit is obtained by increasing either TGC, which increases production per year, or by decreasing FCR, which decreases feed consumption per year.

\section{Dissolved $\mathrm{NH}_{3}-\mathrm{N}$ and Fish Density as Concomitant Limiting Factors}

Figure 2 shows the evolution of the annual profit per farm expressed in euros for different combinations of FCR and TGC. To illustrate the full range of situations and their consequences on the system, 2 extreme values of TGC (7 and 13) are also shown in Fig. 2. As mentioned earlier, decreasing FCR increases profit, 
Table 3. Effect of different values of thermal growth coefficient (TGC) and feed conversion ratio (FCR) on fish production parameters when production is only limited by dissolved $\mathrm{NH}_{3}-\mathrm{N}$ at maximum standing stock (MSS)

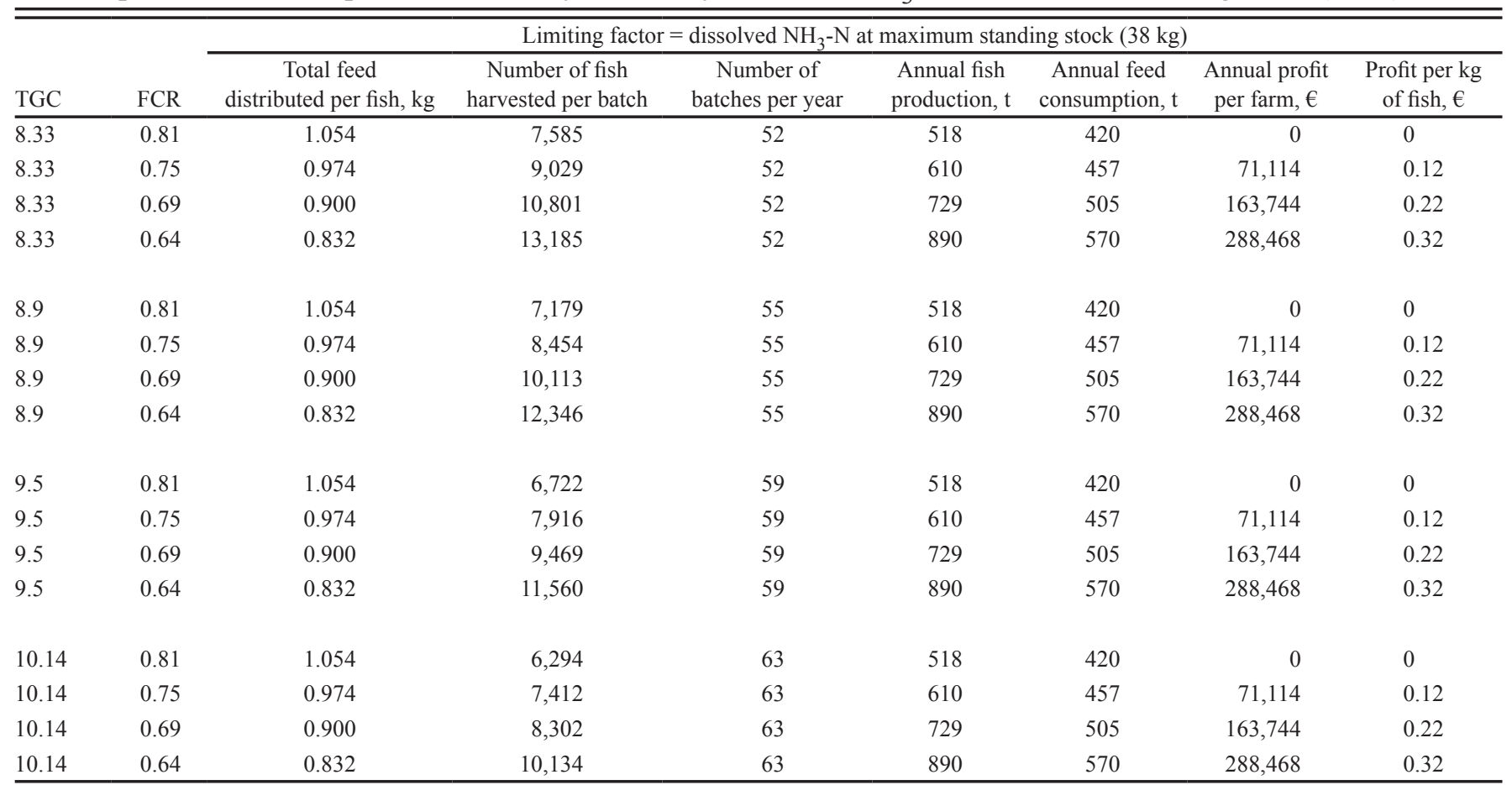

independently of TGC. The rate of increase in profit is, however, different according to the factor limiting fish production, i.e., fish density or dissolved $\mathrm{NH}_{3}-\mathrm{N}$. For example, when TGC is 7, the limiting factor is density, and the dissolved $\mathrm{NH}_{3}-\mathrm{N}$ limitation is never reached. Profit follows, therefore, a linear function (Fig. 2). When TGC has increased to 13 , however, the limiting factor has become dissolved $\mathrm{NH}_{3}-\mathrm{N}$, and the maximum density is never reached. Profit, therefore, follows an exponential function of decreasing FCR (Fig. 2). When TGC progressively increases from 8.33 to 10.15 , the limiting factor of the production system switches from dissolved $\mathrm{NH}_{3}-\mathrm{N}$ to

Table 4. Effect of different values of thermal growth coefficient (TGC) and feed conversion ratio (FCR) on fish production parameters when production is only limited by density at harvest

\begin{tabular}{|c|c|c|c|c|c|c|c|c|}
\hline \multirow[b]{2}{*}{ TGC } & \multirow[b]{2}{*}{ FCR } & \multicolumn{7}{|c|}{ Limiting factor $=$ density at harvest $\left(230 \mathrm{~kg} / \mathrm{m}^{3}\right)$} \\
\hline & & $\begin{array}{c}\text { Total feed } \\
\text { distributed per fish, } \mathrm{kg}\end{array}$ & $\begin{array}{c}\text { Number of fish } \\
\text { harvested per batch }\end{array}$ & $\begin{array}{c}\text { Number of } \\
\text { batches per year }\end{array}$ & $\begin{array}{l}\text { Annual fish } \\
\text { production, } \mathrm{t}\end{array}$ & $\begin{array}{l}\text { Annual feed } \\
\text { consumption, } \mathrm{t}\end{array}$ & $\begin{array}{c}\text { Annual profit } \\
\text { per farm, } €\end{array}$ & $\begin{array}{c}\text { Profit per kg of } \\
\text { fish, } €\end{array}$ \\
\hline 8.33 & 0.81 & 0.811 & 8,846 & 52 & 597 & 484 & 25,369 & 0.04 \\
\hline 8.33 & 0.75 & 0.749 & 8,846 & 52 & 597 & 448 & 66,344 & 0.11 \\
\hline 8.33 & 0.69 & 0.693 & 8,846 & 52 & 597 & 414 & 104,262 & 0.17 \\
\hline 8.33 & 0.64 & 0.640 & 8,846 & 52 & 597 & 383 & 139,257 & 0.23 \\
\hline 8.9 & 0.81 & 0.811 & 8,846 & 55 & 638 & 517 & 38,310 & 0.06 \\
\hline 8.9 & 0.75 & 0.749 & 8,846 & 55 & 638 & 478 & 82,071 & 0.13 \\
\hline 8.9 & 0.69 & 0.693 & 8,846 & 55 & 638 & 442 & 122,567 & 0.19 \\
\hline 8.9 & 0.64 & 0.640 & 8,846 & 55 & 638 & 409 & 159,942 & 0.25 \\
\hline 9.5 & 0.81 & 0.811 & 8,846 & 59 & 681 & 553 & 52,132 & 0.08 \\
\hline 9.5 & 0.75 & 0.749 & 8,846 & 59 & 681 & 511 & 98,868 & 0.15 \\
\hline 9.5 & 0.69 & 0.693 & 8,846 & 59 & 681 & 472 & 142,118 & 0.21 \\
\hline 9.5 & 0.64 & 0.640 & 8,846 & 59 & 681 & 436 & 182,035 & 0.27 \\
\hline 10.14 & 0.81 & 0.811 & 8,846 & 63 & 728 & 590 & 66,894 & 0.09 \\
\hline 10.14 & 0.75 & 0.749 & 8,846 & 63 & 728 & 545 & 116,808 & 0.16 \\
\hline 10.14 & 0.69 & 0.693 & 8,846 & 63 & 728 & 504 & 162,000 & 0.22 \\
\hline 10.14 & 0.64 & 0.640 & 8,846 & 63 & 728 & 466 & 205,630 & 0.28 \\
\hline
\end{tabular}




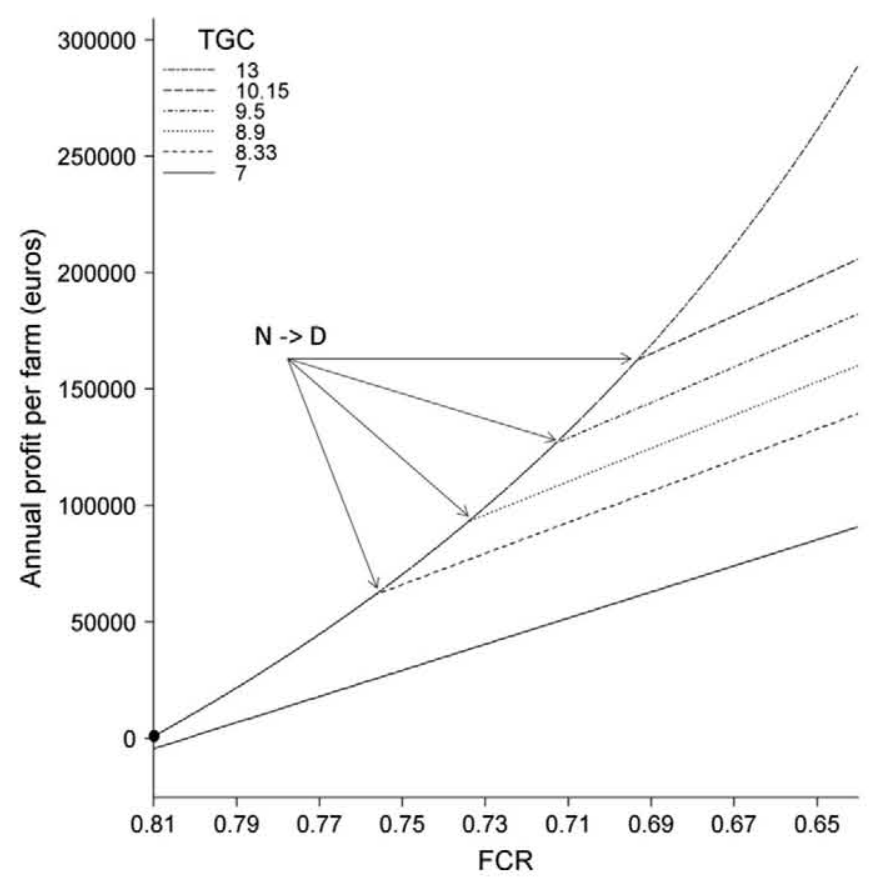

Figure 2. Annual profit per farm as a function of the thermal growth coefficient (TGC) and the feed conversion ratio (FCR). Each line describes the evolution of the profit for a given TGC when FCR decreases as a result of selective breeding. The black spot represents the reference scenario, TGC $=$ 8.33 and $\mathrm{FCR}=0.81$. The arrows illustrate the point where the limiting factor switches from rearing density (D) to dissolved $\mathrm{NH}_{3}-\mathrm{N}(\mathrm{N})$.

density at harvest. Indeed, when dissolved $\mathrm{NH}_{3}-\mathrm{N}$ is the limiting factor, decreasing FCR increases the number of fish harvested per batch. There is a point, however, where the maximum density of fish is reached and density becomes the limiting factor. It can be concluded that for TGC values between 7 and 13, profit initially follows an exponential function of decreasing FCR until the point where density becomes the limiting factor. At this point, the relation with profit to FCR becomes linear. The point of switch is determined by the TGC value.

\section{Economic Values of TGC and FCR}

Economic values of TGC and FCR for different combinations of TGC and FCR are given in Fig. 3. For instance, in the reference scenario $(\mathrm{FCR}=0.81$ and $\mathrm{TGC}=8.33), \mathrm{EV}_{\mathrm{FCR}}$ is $0.13 € / \mathrm{kg}$ of fish and represents the extra profit obtained by improving FCR by $7.6 \%$ (from FCR $=0.81$ to 0.75 ) with the TGC constant at 8.33 (Fig. 3). In the reference scenario, $\mathrm{EV}_{\mathrm{TGC}}$ is $0 € / \mathrm{kg}$ of fish and represents the extra profit obtained by improving TGC by $6.8 \%$ (from $\mathrm{TGC}=8.33$ to 8.90 ) with FCR constant at 0.81 (Fig. 3).

As explained before, EV depend on the limiting factor. In Fig. 3, 4 different zones can be distinguished depending on the limiting factor of the current population mean $\left(\mu_{\mathrm{TGC}}\right.$ and $\left.\mu_{\mathrm{FCR}}\right)$ and on the limiting factor of one generation of selection in either TGC or FCR.
The most significant results are observed in zones 1 and 4 . When the limiting factor is dissolved $\mathrm{NH}_{3}-\mathrm{N}$ (zone 1), $\mathrm{EV}_{\mathrm{TGC}}$ is $0 € / \mathrm{kg}$ of fish because increasing TGC does not bring extra profit. $\mathrm{EV}_{\mathrm{FCR}}$ is, however, equal to $0.14 € /$ $\mathrm{kg}$ of fish. On the other hand, when density is the limiting factor (zone 4), $\mathrm{EV}_{\mathrm{TGC}}$ becomes equal to $0.03 € / \mathrm{kg}$ of fish, and $\mathrm{EV}_{\mathrm{FCR}}$ is 0.05 or $0.06 € / \mathrm{kg}$ of fish.

We also note that when dissolved $\mathrm{NH}_{3}-\mathrm{N}$ is the limiting factor, $\mathrm{EV}_{\mathrm{FCR}}$ decreases when one generation of selection in FCR leads to a situation where density is the limiting factor (zone 2). When density is the limiting factor, $\mathrm{EV}_{\mathrm{TGC}}$ decreases when one generation of selection in TGC leads to a situation where dissolved $\mathrm{NH}_{3}-\mathrm{N}$ is the limiting factor (zone 3).

\section{DISCUSSION}

The bioeconomic model developed in this study was based on farm data and allowed us to investigate the economic impact of improving TGC and FCR at the farm level in a RAS. In a RAS, 2 factors could limit the production level: fish density at harvest time or dissolved $\mathrm{NH}_{3}-\mathrm{N}$ at MSS. The economic impact was expressed via EV calculated as extra profit obtained per $\mathrm{kg}$ of fish produced when improving TGC by $6.8 \%$ or FCR by $7.6 \%$ (simulating one generation of selection). Feed conversion ratio and thermal growth coefficient are the 2 main traits considered by fish breeders because TGC is expected to increase productivity, while FCR decreases feed cost, which represents about $50 \%$ of annual total cost due to the high amounts of protein and lipids in carnivorous fish diets (CNA, 2011).

The results of our study confirm the economic potential of decreasing FCR, but on the other hand, it shows that increasing TGC does not always result in an increase in profitability in RAS. From a theoretical point of view, the calculations of EV are only relevant in a system with optimized management (Amer et al., 1994; Dekkers, 1991). In our bioeconomic model, the farming system was considered optimized as each of the $2 \mathrm{lim}$ iting factors was respected. When dissolved $\mathrm{NH}_{3}-\mathrm{N}$ is the limiting factor, the number of fish stocked per batch depends on FCR and TGC. In this situation, increasing TGC forces a farmer to decrease the number of fish stocked in order to account for the increase in dissolved $\mathrm{NH}_{3}-\mathrm{N}$ excretion. When dissolved $\mathrm{NH}_{3}-\mathrm{N}$ is the limiting factor, therefore, TGC does not increase productivity. On the other hand, decreasing FCR always decreases feed cost per unit of fish produced with both limiting factors of dissolved $\mathrm{NH}_{3}-\mathrm{N}$ and density.

Calculation of $\mathrm{EV}$ shows that $\mathrm{EV}_{\mathrm{TGC}}$ and $\mathrm{EV}_{\mathrm{FCR}}$ vary and depend on the limiting factor of the current generation and on the limiting factor operating at the next generation of selection. For TGC, when dissolved 


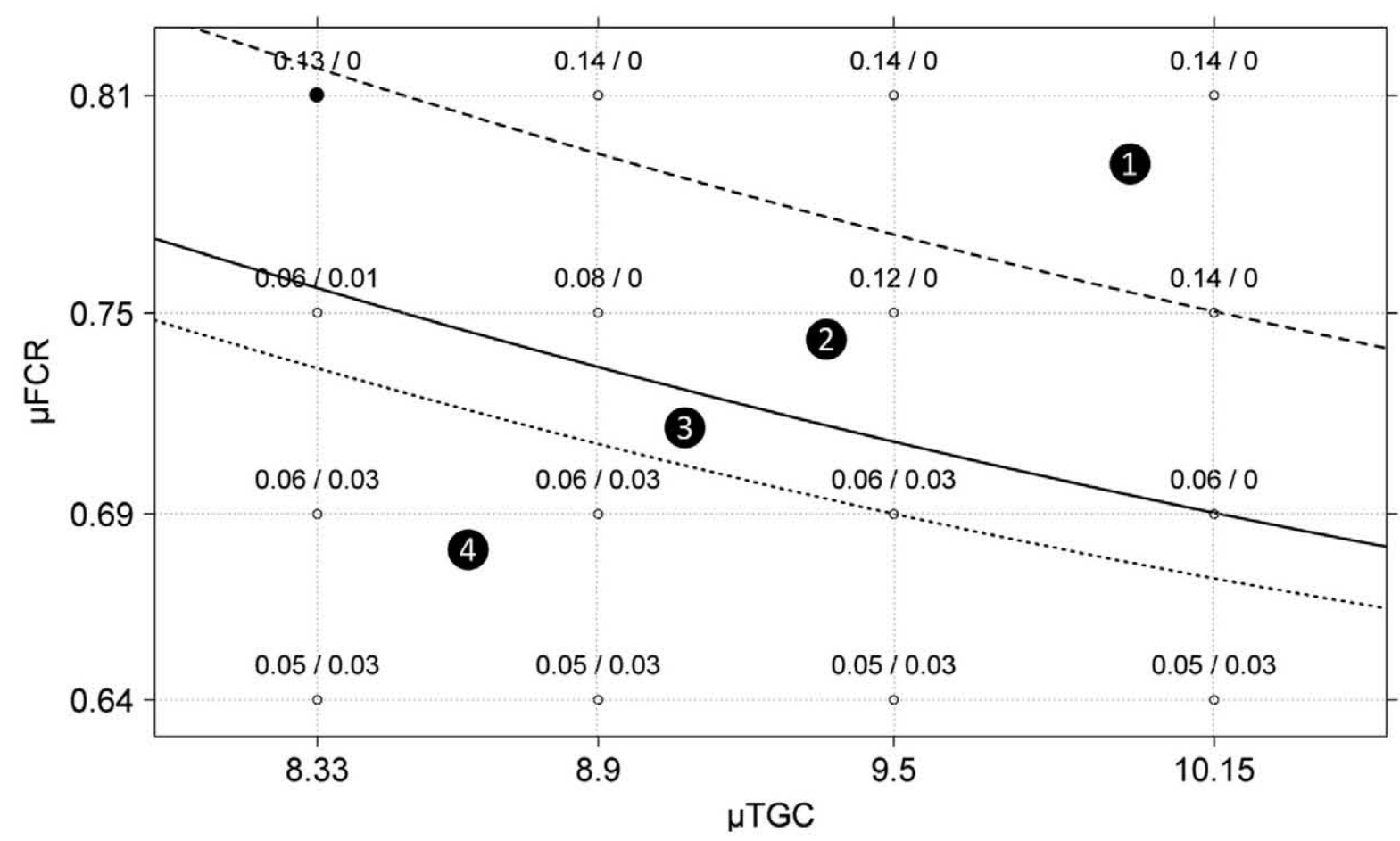

Figure 3. Economic values (EV) of the feed conversion ratio (FCR) and the thermal growth coefficient (TGC) for 16 combinations of $\mu_{\mathrm{TGC}}$ and $\mu_{\mathrm{FCR}}$ classified in 4 different zones depending on the limiting factor of the current population mean $\left(\mu_{\mathrm{TGC}}\right.$ and $\left.\mu_{\mathrm{FCR}}\right)$ and on the limiting factor after one generation of selection. In zone 1, dissolved $\mathrm{NH}_{3}-\mathrm{N}$ is the limiting factor, and one generation of selection in either TGC or FCR does not change this. In zone 2, dissolved $\mathrm{NH}_{3}-\mathrm{N}$ is the limiting factor and after one generation of selection in FCR density becomes the limiting factor. In zone 3, density is the limiting factor, and after one generation of selection in TGC, dissolved $\mathrm{NH}_{3}-\mathrm{N}$ becomes the limiting factor. In zone 4, density is the limiting factor, and one generation of selection TGC or FCR does not change this. The black spot represents the reference scenario, $\mathrm{TGC}=8.33$ and $\mathrm{FCR}=0.81$.

$\mathrm{NH}_{3}-\mathrm{N}$ is the limiting factor, $\mathrm{EV}_{\mathrm{TGC}}$ is always zero, meaning that increasing TGC does not have any impact on annual profit per farm. These results can be partly explained by our choices for the modeling of $\mathrm{FCR}_{\mathrm{wn}}$ (Eq. [4]) and FCR (Eq. [22]). According to James (1982), EV of traits included in the breeding goal should be calculated regardless of correlations among those traits. We, therefore, modeled $\mathrm{FCR}_{\mathrm{Wn}}$ as a function of fish weight to make TGC and FCR independent. We also considered, according to farm data, that mortality was independent from TGC. The consequence of these assumptions is that changes in TGC neither affect $\mathrm{FCR}_{\mathrm{wn}}$ nor FCR.

On the other hand, when the limiting factor is density for both $\mu_{\mathrm{TGC}}$ and $\mu_{\mathrm{TGC}}+\Delta_{\mathrm{TGC}}, \mathrm{EV}_{\mathrm{TGC}}$ is $0.03 € /$ $\mathrm{kg}$ of fish. In most fish species, EV are lacking, and the economic impact of breeding programs is not known. However, a study by Gjerde and Olsen (1990) on Atlantic salmon (Salmo salar) found that the EV of improving growth rate by $10 \%$ in salmon farming was about 0.09 $€ / \mathrm{kg}$ of fish (Gjedrem et al., 2012). This difference can be due to the low margin between production costs and revenues of African catfish compared to Atlantic salmon.

Economic values of FCR confirm the importance of feed in farm profitability because FCR always gets a positive $\mathrm{EV}$ whatever the limiting factors. $\mathrm{EV}_{\mathrm{FCR}}$ can reach $0.14 € / \mathrm{kg}$ of fish when $\mathrm{NH}_{3}-\mathrm{N}$ is the limiting factor, which is higher than the maximum value of $0.05-0.06 € / \mathrm{kg}$ of fish when density is the limiting factor. Improving FCR through selective breeding, therefore, increases the annual profit per farm. The percentage of improvement tested in this study (7.6\%), however, represents the genetic gain of one generation of selection on FCR only and is purely hypothetical. Apart from rainbow trout, there are no genetic parameter estimates for FCR in any commercial fish species. Thodesen et al. (1999) found a reduction in FCR of $4 \%$ per generation as a correlated response to selection for growth in Atlantic salmon. In rainbow trout, Kause et al. (2006) predicted that selection for daily gain would only increase daily gain by $17.6 \%$ per generation and simultaneously would increase feed efficiency (1/FCR) by $8.4 \%$. This suggests a positive correlation between feed efficiency and growth rate, which is consistent with results in terrestrial livestock species, such as pig and poultry (Clutter and Brascamp, 1998; Crawford, 1990). Other studies in different fish species show a more complex picture. Thodesen et al. (2001), for instance, found a phenotypic correlation of 0.79 between feed efficiency and growth rate, while Silverstein et al. (2005) found a moderate correlation of -0.38 between residual feed intake and growth rate. Due to this moderate correlation, Silverstein et al. (2005) suggested that selection on growth rate only will not necessarily improve feed utilization efficiency. In parallel, some other studies in salmonids did not show any correlation between growth rate and feed efficiency 
and showed that genetic gain in growth was due to higher feed intake, while feed efficiency remained unchanged (Mambrini et al., 2004; Sanchez et al., 2001).

Assumptions on the links between FCR and growth rate can have a high impact on the profitability of fish breeding programs. Ponzoni et al. (2007), for instance, simulated a genetic improvement program in Nile tilapia including harvest weight, survival rate, and feed intake in the breeding goal. One of their assumptions was that the genetic and the phenotypic correlation between harvest weight and feed intake was 0.85 . The practical consequence of these correlations is that improving harvest weight will increase feed intake, but by a lower rate, resulting in a lower FCR. In their study, the estimated benefit over cost ratio of implementing a breeding program ranged from 8.5 to 60 . This high positive economic return, however, was mostly due to a better feed conversion ratio correlated to the genetic improvement of harvest weight.

Gjedrem et al. (2012) suggested running a simple breeding program including only growth rate in the breeding goal in order to limit the initial investment and, consequently, to incite farmers to use improved stock. Considering no correlation between TGC and FCR, implementing a breeding program for growth rate would be profitable only when density is the limiting factor. Considering a negative correlation between TGC and FCR, however, implementing a breeding program for growth rate would also lead to a small improvement in FCR. Gjedrem et al. (2012) estimated this correlated response to be $2.76 \%$ per generation in Atlantic salmon. Assuming a percentage of improvement of $6.8 \%$ in TGC and $2.76 \%$ in FCR, we can estimate the economic benefit of implementing such breeding program in African catfish in RAS. In the reference scenario $(\mathrm{TGC}=8.33$ and FCR $=0.81$ ), with dissolved $\mathrm{NH}_{3}-\mathrm{N}$ as the limiting factor, the total extra profit obtained from one generation of selection would be $0.05 € / \mathrm{kg}$ of fish $\left(\mathrm{EV}_{\mathrm{TGC}}=0 € / \mathrm{kg}\right.$ of fish $+\mathrm{EV}_{\mathrm{FCR}}=0.05 € / \mathrm{kg}$ ). If the production is limited by density (still in the reference scenario), the total benefit obtained from one generation of selection would also be $0.05 € / \mathrm{kg}$ of fish $\left(\mathrm{EV}_{\mathrm{TGC}}=0.02 € / \mathrm{kg}\right.$ of fish + $\mathrm{EV}_{\mathrm{FCR}}=0.03 € / \mathrm{kg}$ of fish).

Therefore, in this particular situation of African catfish raised in RAS, implementing a breeding program that only aims at improving TGC would always be profitable only in a situation of density limitation, whether or not there is a genetic correlation between TGC and FCR. The implication of this finding is that RAS farms should be designed according to maximum rearing densities, using larger biofilters than needed in order to remain in the situation of density limitation and to obtain higher profit from improving growth rate only. Using a larger biofilter, however, would increase the fixed costs of the farm.
Our findings can also be extended to other livestock systems where animal manure can cause greenhouse gas emissions and eutrophication. In the UK, the government defined nitrate vulnerable zones, which designate agricultural lands draining nitrates to vulnerable or polluted waters. In these areas, farmers must comply with a limitation on the amount of nitrogen from livestock manure applied on their farm whether by grazing animals (cattle, sheep, deer, goats, and horses) or by spreading (Defra, 2013). This limitation corresponds to $170 \mathrm{~kg}$ of nitrogen per hectare and per year but extra manure production can be stocked in manure storage facilities. However, storage of manure could be forbidden in the future, and farmers could have to deal with a strict limitation. In this case, therefore, faster growing animals (with the same feed efficiency) will have a similar impact as faster growing fish in RAS when dissolved $\mathrm{NH}_{3}-\mathrm{N}$ is the limiting factor. Faster growing animals would increase production rates, but farmers would have to rear fewer animals, which will then result in a zero economic value for growth rate.

To conclude, we found that the economic values of TGC and FCR changed depending on the factors limiting fish production in a closed containment system such as a RAS. The economic value of growth rate is zero when dissolved $\mathrm{NH}_{3}-\mathrm{N}$ is the limiting factor. Hence, it is not always economically profitable to breed for faster growing fish. On the other hand, FCR always get a positive economic value, but economic values of FCR are higher when $\mathrm{NH}_{3}-\mathrm{N}$ is the limiting factor. Those results show the importance of modeling the entire farming system to calculate economic values in order to develop efficient breeding programs in aquaculture for the future.

\section{LITERATURE CITED}

Amer, P. R., G. C. Fox, and C. Smith. 1994. Economic weights from profit equations: appraising their accuracy in the long run. Anim. Sci. 58:11-18.

Cho, C. Y., and S. J. Kaushik. 1990. Nutritional energetics in fish: energy and protein utilization in rainbow trout (Salmo gairdneri). World Rev. Nutr. Diet. 1:132-172.

Clutter, A. C., and E. W. Brascamp. 1998. Genetics of performance traits. In: M. F. Rotschild and A. Ruvinsky, editors, The genetics of the pig. CAB Int., Wallingford, UK. p. 427-455.

CNA. 2011. Quelle place pour les protéines animales transformées (PAT) dans l'alimentation des porcs, des volailles et des poissons? Cons. Natl. l'Aliment., Paris.

Cowey, C. B., and C. Y. Cho. 1991. Nutritional strategies and aquaculture waste. Proc. 1st Int. Symp. Nutr. Strategies Manage. Squaculture Waste. Univ. Guelph, Guelph, Ontario, Canada.

Crawford, R. D. 1990. Poultry breeding and genetics. Elsevier, Oxford, UK.

Dekkers, J. C. M. 1991. Estimation of economic values for dairy cattle breeding goals: Bias due to sub-optimal management policies. Livest. Prod. Sci. 29:131-149. 
Defra. 2013. Guidance on complying with the rules for Nitrate Vulnerable Zones in England for 2013 to 2016, Dep. of Environ. Food and Rural Affairs, London.

Dumas, A., J. France, and D. P. Bureau. 2007. Evidence of three growth stanzas in rainbow trout (Oncorhynchus mykiss) across life stages and adaptation of the thermal-unit growth coefficient. Aquaculture 267:139-146.

FAO. 2012. FAO yearbook. Fishery and aquaculture statistics. 2010, Food and Agric. Organ. of the U. N., Rome. p. 73.

Gibson, J. P. 1989. Selection on the major components of milk: alternative methods of deriving economic weights. J. Dairy Sci. 72:3176-3189.

Gjerde, B., and B. Olsen. 1990. Economic value of breeding program (Økonomisk Verdi av avlsarbeidet). Husdyrforsøksmøtet 1990. Akvakultur. Aktuelt fra Statens Fagtjeneste for landbruket, No. 5, p. 61-65. (In Norwegian)

Gjedrem, T., N. Robinson, and M. Rye. 2012. The importance of selective breeding in aquaculture to meet future demands for animal protein: A review. Aquaculture 350-353:117-129.

Groen, A.F. 1988. Derivation of economic values in cattle breeding: A model at farm level. Agric. Syst. 27:195-213.

Groen, A. 1989. Economic values in cattle breeding. II. Influences of production circumstances in situations with output limitations. Livest. Prod. Sci. 22:17-30.

Hazel, L. N. 1943. The genetic basis for constructing selection indexes. Genetics 28:476-490.

James, J. 1982. Economic aspects of developing breeding objectives: general considerations. p. 107-118, In: J. S. F., Barker, K. Hammond, and A. E. McClintock, editors, Future developments in the genetic improvement of animals. Academic, Sydney, New South Wales, Australia.

Kause, A., D. Todin, D. F. Houlihan, S. A. M. Martins, E. A. Mäntysaari, O. Ritola, and K. Ruohonen. 2006. Feed efficiency of rainbow trout can be improved through selection: Different genetic potential on alternative diets. J. Anim. Sci. 84:807-817.

Mambrini, M., F. Médale, M. P. Sanchez, B. Recalde, B. Chevassus, L. Labbé, E. Quillet, and T. Boujard. 2004. Selection for growth in brown trout increases feed intake capacity without affecting maintenance and growth requirements. J. Anim. Sci. 82:28652875.

Martins, C. I. M., E. H. Eding, M. C. J. Verdegem, L. T. N. Heinsbroek, O. Schneider, J. P. Blancheton, E. Roque d'Orbcastel, and J. A. J. Verreth. 2010. New developments in recirculating aquaculture systems in Europe: A perspective on environmental sustainability. Aquacult. Eng. 43:83-93.

Ponzoni, R. W., N. H. Nguyen, and H. L. Khaw. 2007. Investment appraisal of genetic improvement programs in Nile tilapia (Oreochromis niloticus). Aquaculture 269:187-199.

R Development Core Team. 2008. R: A language and environment for statistical computing. R Found. for Stat. Comput., Vienna.

Robinson, E. H., and M. H. Li. 2010. Channel catfish, Ictalurus punctatus, size and feed conversion ratio. J. World Aquacult. Soc. 41:829-833.

Sae-Lim, P., H. Komen, A. Kause, J. A. M. van Arendonk, A. J. Barfoot, K. E. Martins, and E. Parsons. 2012. Defining desired genetic gains for rainbow trout breeding objective using analytic hierarchy process. J. Anim. Sci. 90:1766-1776.

Salhi, M., M. Bessonart, G. Chediak, M. Bellagamba, and D. Carnevia. 2004. Growth, feed utilization and body composition of black catfish, Rhamdia quelen, fry fed diets containing different protein and energy levels. Aquaculture 231:435-444.
Sanchez, M. P., B. Chevassus, L. Labbé, E. Quillet, and M. Mambrini. 2001. Selection for growth of brown trout (Salmo trutta) affects feed intake but not feed efficiency. Aquat. Living Resour. $14: 41-48$.

Silverstein, J. T., M. Hostuttler, and K. P. Blemings. 2005. Strain differences in feed efficiency measured as residual feed intake in individually reared rainbow trout, Oncorhynchus mykiss (Walbaum). Aquacult. Res. 36:704-711.

Silverstein, J. T., R. L. Vallejo, Y. Palti, T. D. Leeds, C. E. Rexroad, III, T. J. Welch, G. D. Wiens, and V. Ducrocq. 2009. Rainbow trout resistance to bacterial cold-water disease is moderately heritable and is not adversely correlated with growth. J. Anim. Sci. 87:860-867.

Thodesen, J., B. Gjerde, B. Grisdale-Helland, and T. Storebakken. 2001. Genetic variation in feed intake, growth and feed utilization in Atlantic salmon (Salmo salar). Aquaculture 194:273281.

Thodesen, J., B. Grisdale-Helland, S. J. Helland, and B. Gjerde. 1999. Feed intake, growth and feed utilization of offspring from wild and selected Atlantic salmon (Salmo salar). Aquaculture 180:237-246.

van Rijn, J. 2013. Waste treatment in recirculating aquaculture systems. Aquacult. Eng. 53:49-56.

van Weerd, J. H., K. H. A. Khalaf, F. J. Aartsen, and P. A. T. Tijssen. 1999. Balance trials with African catfish Clarias gariepinus fed phytase-treated soybean meal-based diets. Aquacult. Nutr. $5: 135-142$.

\section{APPENDIX}

Appendix Table 1. Composition of the feed

\begin{tabular}{lc}
\hline \hline Composition & Quantity, in $\mathrm{g} / \mathrm{kg}$ of feed \\
\hline Protein & 45 \\
Crude fat & 12.5 \\
Crude ash & 9 \\
Other Carbohydrates & 22.5 \\
Phosphorus & 1.1 \\
\hline
\end{tabular}

\section{APPENDIX 2}

\section{Equation [11]:}

N_suspended $\mathrm{n}_{\mathrm{n}}$ is calculated using the digestibility of protein (dig_P $=90 \%$ ) and the solubility of suspended N (sol_susp $=15 \%)$ :

$\mathrm{N} \_\operatorname{suspended}_{\mathrm{n}}=[(\mathrm{N}$ feed_intake $\mathrm{n} \times(1$-dig_P $))+$ N_feed_waste $\mathrm{n}] \times(1-$ sol_susp $)$

N_suspended ${ }_{\mathrm{n}}=\left[\left(72 \times \mathrm{DWG}_{\mathrm{n}} \times \mathrm{FCR}_{\mathrm{n}} \times\right.\right.$ $(1-$ dig_P $\left.))+\left(0.72 \times \mathrm{DWG}_{\mathrm{n}} \times \mathrm{FCR}_{\mathrm{n}}\right)\right] \times$ (1-sol_susp) 
N_suspended ${ }_{\mathrm{n}}=6.732 \times \mathrm{FCR}_{\mathrm{Wn}} \times \mathrm{DWG}_{\mathrm{n}}$

Equation [13]:

N_dissolved $\mathrm{n}=\mathrm{N} \_$excretion $_{\mathrm{n}}+\mathrm{N}_{\text {_feed_waste }}$ - $^{-}$

N_suspended ${ }_{n}$

$\mathrm{N} \_$dissolved $_{\mathrm{n}}=\mathrm{N} \_$feed_intake $\mathrm{n}-\mathrm{N}$ fish $_{\mathrm{n}}+$

$\mathrm{N} \_$feed_waste ${ }_{\mathrm{n}}-\overline{\mathrm{N}}_{-}$suspended $_{\mathrm{n}}$

N_dissolved $\mathrm{n}=\left(72 \times \mathrm{DWG}_{\mathrm{n}} \times \mathrm{FCR}_{\mathrm{Wn}}\right)-(25 \times$ $\left.\mathrm{DWG}_{\mathrm{n}}\right)+\left(0.72 \times \mathrm{DWG}_{\mathrm{n}} \times \mathrm{FCR}_{\mathrm{Wn}_{\mathrm{n}}}\right)-(6.732 \times$ $\left.\mathrm{FCR}_{\mathrm{Wn}} \times \mathrm{DWG}_{\mathrm{n}}\right)$

N_dissolved $=\left(65.988 \times \mathrm{DWG}_{\mathrm{n}} \times \mathrm{FCR}_{\mathrm{Wn}}\right)-$ $\left(25 \times \mathrm{DWG}_{\mathrm{n}}\right)$

Equation [14]:

Emission of $\mathrm{NH}_{3}-\mathrm{N}$ in effluent water can be calculated using the retention capacity of the mechanic filter (retention_susp $=90 \%$ ) and the percentage of nitrification (perct_nitri $=100 \%)$ :

N_eff $\mathrm{n}=(1-$ retention_susp $) \times \mathrm{N}_{\text {_suspended }}+$ $(1-$ perct_nitri $) \times$ N_dissolved $\mathrm{n}$

N_eff ${ }_{\mathrm{n}}=0.1 \times$ N_suspended $_{\mathrm{n}}$

\section{APPENDIX 3}

Equation [15]:

COD_waste $\mathrm{n}=($ protein $\times 1.3+$ crude_fat $\times 2.9+$ carbs $\times 1.07) \times\left(\mathrm{DFI}_{\mathrm{n}} \times 0.01\right)$

COD_waste $=($ protein $\times 0.013+$ crude_fat $\times$ $0.029+\operatorname{carbs} \times 0.0107) \times \mathrm{DFI}_{\mathrm{n}}$

\section{Equation [16]:}

COD_excretion ${ }_{\mathrm{n}}$ is calculated using digestibility of proteins (Dig_P $=90 \%)$, crude fat $($ Dig_F $=$ 90\%), and carbohydrates (Dig_C $=60 \%$ ):

COD_excretion $n=\left[\left(\right.\right.$ protein $\times\left(1-D i g \_P\right) \times$ $1.3)+($ crude_fat $\times(1$-Dig_F $) \times 2.9)+($ carbs $\times$ $\left(1-\right.$ Dig_C $\left.\left._{-} \times 1.07\right)\right] \times \mathrm{DFI}_{\mathrm{n}}$

COD_excretion $n=($ protein $\times 0.13+$ crude_fat $\times$ $0.29+$ carbs $\times 0.428) \times \mathrm{DFI}_{\mathrm{n}}$

\section{Equation [17]:}

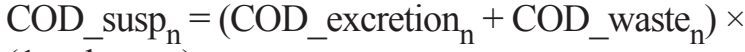
(1-sol_susp)

COD_susp $p_{\mathrm{n}}=($ protein $\times 0.12155+$ crude_fat $\times$

$0.27155+$ carbs $\times 0.372895) \times \mathrm{DFI}_{\mathrm{n}}$

COD_sludge $\mathrm{n}_{\mathrm{n}}=\mathrm{COD} \_\mathrm{susp}_{\mathrm{n}} \times(1-$ retention_susp $)$

COD_sludge $\mathrm{n}_{\mathrm{n}}=($ protein $\times 0.012155+$ crude_fat $\times$ $0.027155+$ carbs $\times 0.0372895) \times \mathrm{DFI}_{\mathrm{n}}$

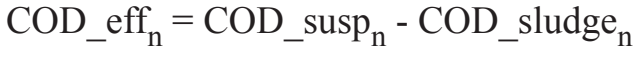

COD_eff $\mathrm{n}=($ protein $\times 0.109395+$ crude_fat $\times$ $0.244395+$ carbs $\times 0.3356055) \times \mathrm{DFI}_{\mathrm{n}}$ 
References

This article cites 23 articles, 5 of which you can access for free at: http://www.journalofanimalscience.org/content/92/12/5394\#BIBL 